\title{
The Effect of Communication, Information, Education on the Knowledge Level of Acceptors about Side Effects of 3-Month Contraceptive Injection at BPM L Banjaranyar Village
}

\author{
Safira Rizky M⿻1, Wulan Margiana ${ }^{2}$ \\ ${ }^{1,2}$ Department of Health, Universitas Muhammadiyah Purwokerto, Indonesia
}

\begin{tabular}{l} 
ARTICLE INFO \\
\hline Article history: \\
DOI: \\
10.30595/pshms.v2i.246 \\
Submitted: \\
December 6, 2021 \\
Accepted: \\
January 21, 2022 \\
Published: \\
January 26, 2022 \\
\hline
\end{tabular}

\section{Keywords:}

$\mathrm{KIE}$; 3 months injectable KB; side effects

\begin{abstract}
The increasing world population will cause many problems in various fields, especially in the social and economic fields. Thus, the government has taken an action by launching a family planning program to control the rate of population growth. One of the most popular family planning programs is the 3-month injection KB with side effects. This study aimed to determine the effect of the provision of communication, information, and education regarding the side effects of using a 3-month injection of KB on the level of knowledge of family planning acceptors about the side effects of using KB in BPM L in Banjaranyar village. This was comparative research with a quantitative approach. The number of samples was 15 respondents in both the intervention group and the control group. In addition, the data were collected using a questionnaire and were analyzed using the Fisher test. The result showed that there were 15 respondents $(100 \%)$ in the intervention group with good predicate, while the level of knowledge in the control group with good predicate was 8 respondents (53\%) and 7 respondents $(40 \%)$ not good predicate. Then the P-value obtained from the Fisher test was 0.006, so the $\mathrm{p}$-value was 0.05 . There was an effect of the provision of communication, information, and knowledge regarding the side effects of using 3-month injectable contraceptives on the level of knowledge of family planning acceptors in BPM midwives in Banjaranyar village.
\end{abstract}

This work is licensed under a Creative Commons Attribution 4.0 International License.

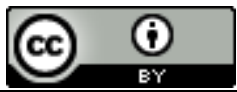

Corresponding Author:

Wulan Margiana,

Department of Health, Universitas Muhammadiyah Purwokerto,

Soepardjo Rustam Street KM. 7, Banyumas, Indonesia

Email: wulanmargiana@ump.ac.id

\section{INTRODUCTION}

The increasing number of world population will cause many problems in various fields, especially in the social and economic fields. Uncontrolled population growth can cause a population explosion, and in the end there will be difficulties in distributing prosperity in society. [1]

Family planning is an effort to create a quality family through promotion, protection, and assistance in realizing reproductive rights as well as providing services, arrangements and support needed to form a family with the ideal marriageable age, regulating the number, distance, and ideal age of childbearing, regulate pregnancy and foster resilience and child welfare. [2]

Accordingtothe BKKBN, active family planning among PUS in Indonesia in 2019 was 62.5\%, a decrease from the previous year, which was 63.27\%. While the RPJMN target to be achieved in 2019 is $66 \%$. The results of the 2017 IDHS also show a higher number for active family planning, which is $63.6 \%$. The highest number of EFAs in Indonesia was obtained in West Java with a total of 7,964,464 pairs. The coverage of active family planning participants according to modern contraceptive methods in 2019 was as follows: Injectable contraceptives $63.7 \%$, PIL contraceptives 17.0\%, IUD/IUD contraceptives 7, 4\%, MOP $0.5 \%$, MOW 2.7\%, Implants 7.4\%, Condoms 1.2\%. [3] 
Based on the results of a preliminary study that the researchers conducted at BPM "L" in the village of Banjaranyar, they obtained data on the number of injectable hormonal family planning acceptors who came to this BPM as many as 53 family planning acceptors. According to information from Midwife "L" that most of the almost $50 \%$ of the acceptors complained of side effects, namely menstrual disorders, and $40 \%$ of the acceptors complained of weight gain, and $10 \%$ of the acceptors did not complain about the side effects they experienced.

In a study conducted by Ayu Devita (2018) on the Overview of Side Effects of KB Injections with Depo Medroxy Progesterone Acetate on Acceptors at Independent Practice Midwives (BPM) in the Working Area of Sako Palembang Village in 2017, it was found that 97 research respondents experienced side effects based on Menstrual Disorders, namely Amenorrhea 48 respondents (49.5\%), Spotting 23 respondents (23.7\%), Metrorargia 14 respondents (14.4\%), and Menorargia 12 respondents $(12.4 \%)$. Based on Weight Gain, 83 respondents $(85.6 \%)$ experienced weight gain and 14 respondents $(14.4 \%)$ did not experience weight gain. Based on cloasma, there were 38 respondents who had cloasma $(39.2 \%)$ and those who did not experience cloasma were 59 respondents $(60.8 \%)$.

Based on the results of Ignata Apolonia's research (2018) about the description of the level of knowledge of hormonal family planning acceptors about the side effects of hormonal contraception at the Gentungan Gowa Health Center, it was found that the level of knowledge of acceptors was divided into three parts, namely according to the age of family planning acceptors with the results that acceptors aged $>35$ years were more understanding about Hormonal family planning side effects are as much as (85.7\%), if according to the acceptor's level of education the higher the level of education, the level of knowledge about side effects of family planning is increasing by as much as $(50 \%)$, if according to the acceptor's occupation it affects the level of knowledge about side effects as much as $(83,5 \%)$.

Contraceptive services are a series of activities including the provision of IEC, counseling, screening medical eligibility, administering contraception, insertion or removal, and handling side effects or complications in an effort to prevent pregnancy. [4]

KIE stands for Communication, Information, and Education. According to (Effendy, 1998 in Sugeng, 2019), communication is the exchange of thoughts or information in order to create a sense of mutual understanding and trust, for the sake of realizing good relations between one person and another. Health communication is the process of delivering messages containing matters relating to health and conveyed by the sender of the message to the recipient through various media that are considered appropriate. [5]

\section{METHOD}

This research uses unpaired categorical comparative research method with quantitative approach. This study uses a posttest only control design.The population of this study were mothers who used 3-month injectable contraception who came in July - August at BPM "L" Banjaranyar Village. The sample in this study was divided into 2 groups in the experimental group and in the control group each of 15 people using the Lameshow formula. The sampling technique used is purposive sampling.

The independent variable (independent variable) in this study was the administration of IEC with side effects of 3 months of family planning. The dependent variable (dependent variable) in this study is the level of knowledge of family planning acceptors.

In this study, the researchers adopted a questionnaire from previous research that has been validated, for the questionnaire using a questionnaire from a study by Dedah Umilah Maswatu (2017) with the research title "Overview of Knowledge Levels of Injectable Family Planning Acceptors About Side Effects of Progestin Injecting Contraception at Gamping 1 Health Center, Sleman Yogyakarta". [5] It is divided into 3 parts of the questionnaire, namely no.1-9 discussing the Types of Side Effects of Progestin Injections, no. 1019 discusses the Symptoms and Complaints of side effects of Progestin Injections, no. 20-28 discusses the handling of side effects of progestin injections. While the way to measure it is using a questionnaire containing questions with 2 alternative answers, namely true and false. If the correct answer gets a score of 1 (highest score) and if the wrong answer gets a score of 0 (lowest score). The results of the questions will be calculated and analyzed and will be categorized into 2 parts Good and Bad. Data analysis used the ChiSquare statistical test with an alternative test in the form of the Fisher test. 


\section{RESULTS AND DISCUSSION}

2.1.Univariat

Tabel 1.Frequency Distribution of the Characteristics of Respondent Injectable of Family Planning in BPM "L" Banjarnyar Village

\begin{tabular}{|c|c|c|c|c|}
\hline \multirow[b]{2}{*}{ Characteristics of Respondents } & \multicolumn{2}{|l|}{ Intervention } & \multicolumn{2}{|l|}{ Control } \\
\hline & Frequency & Percentage & Frequency & Percentage \\
\hline \multicolumn{5}{|l|}{ Age } \\
\hline $20-35$ & 9 & $60 \%$ & 7 & $46,60 \%$ \\
\hline$>35$ & 6 & $40 \%$ & 8 & $53,30 \%$ \\
\hline \multicolumn{5}{|l|}{ Education } \\
\hline Primary School & 5 & $33,30 \%$ & 5 & $26,60 \%$ \\
\hline Junior High School & 5 & $33,30 \%$ & 6 & $40,00 \%$ \\
\hline Senior High School & 4 & $26,70 \%$ & 4 & $27 \%$ \\
\hline College & 1 & $6,70 \%$ & 0 & $0,00 \%$ \\
\hline \multicolumn{5}{|l|}{ Profession } \\
\hline Housewife & 12 & $80 \%$ & 10 & $66,60 \%$ \\
\hline Entrepreneur & 2 & $13,30 \%$ & 5 & $33,30 \%$ \\
\hline Civil Servants & 1 & $6,70 \%$ & 0 & $0,00 \%$ \\
\hline \multicolumn{5}{|l|}{ Number Of Children } \\
\hline 1 & 4 & $26,70 \%$ & 2 & $33,30 \%$ \\
\hline $2-3$ & 10 & $66,70 \%$ & 13 & $86,60 \%$ \\
\hline$>3$ & 1 & $6,70 \%$ & 0 & $0,00 \%$ \\
\hline \multicolumn{5}{|l|}{ Long Use Of Contraceptive } \\
\hline$<1$ Years & 2 & $13,30 \%$ & 0 & $0,00 \%$ \\
\hline 1-3 Years & 11 & $73,30 \%$ & 10 & $66,60 \%$ \\
\hline$>3$ years & 2 & $13,30 \%$ & 5 & $33 \%$ \\
\hline
\end{tabular}

Based on the results of the research that has been carried out, there are several characteristics of respondents that affect the level of knowledge of 3-month injectable family planning acceptors about the side effects of 3-month injections in PMB "L" and the characteristics used from 30 respondents. From the results of the study, it was found that the characteristics of the respondents were as follows: The age of the respondents in this study was in the range of 20-35 years, >35 years with the results of the study that in the intervention group the majority of respondents aged 20-35 years were 10 respondents $(66.6 \%)$.

The education of the respondents in this study there are several levels of education from elementary, junior high, high school, and university (Diploma and Bachelor) with the results of the study the majority of respondents in the intervention group, namely SD-SMP with a total of 5 respondents each (33.3\%), while in the control group the majority, namely junior high school as many as 6 respondents $(40 \%)$.

The occupations of the respondents obtained in this study include IRT (housewives), self-employed, civil servants with the results of the study the majority of respondents' occupations are IRT (housewives) both from the intervention group as many as 12 respondents $(80 \%)$ and from the control group as many as 10 respondents $(66.6 \%)$. The number of children respondents in this study were $<1$ year, $1-3$ years, $>3$ years with the results of the study the majority of respondents having children in the range of 1-3 children from the intervention group as many as 10 respondents $(66.6 \%)$ and in the control group as many as 13 respondents $(86.6 \%)$. The duration of the use of the 3 -month injectable $\mathrm{KB}$ consists of three categories, namely $<1$ year, 1-3 years, > 3 years with the results of the study the majority of respondents using this KB with a time span of 1-3 years with the intervention group as much as (73.30\%) and in the control group as much as (66.60\%). The perceived complaints consisted of no complaints, changes in body weight, menstrual disorders, severe headaches with the results of the study the majority of complaints felt in the intervention group experiencing menstrual disorders as many as 7 respondents (47\%) and in the control group experiencing changes in body weight as many as 7 respondents. (47\%), and the most infrequent complaint was dizziness as many as 2 respondents $(13,3 \%)$. 


\subsection{Bivariat}

Table 2. Konwledge level of respondents in the intervention group and control group

\section{Knowledge level}

\begin{tabular}{llrrr}
\multicolumn{1}{c}{ Given CIE } & Good & \multicolumn{1}{c}{ Bad } & Total & Nilai P Value \\
\hline Given & $15(65,2 \%)$ & 0 & $15(50 \%)$ & \\
Not Given & $8(34,8 \%)$ & $7(100 \%)$ & $15(50 \%)$ & \\
Total & $\mathbf{2 3 ( 1 0 0 \% )}$ & $\mathbf{7 ( 1 0 0 \% )}$ & $\mathbf{3 0}(\mathbf{1 0 0 \% )}$ & $\mathbf{0 , 0 0 6}$ \\
\hline
\end{tabular}

Based on the results of the study in table 2. shows the results obtained that the intervention group that was given IEC was 15 respondents with a good level of knowledge (65.2\%), while in the control group that was not given IEC who got a good level of knowledge as many as 8 respondents (34.8\%) and 7 respondents $(100 \%)$ had poor knowledge levels.

The results of the study after the Chi-Square test got the results that it did not meet the chi-square test because the expected count value was less than 5 a maximum of $20 \%$ of the number of cells while in this study it was more than $20 \%$ so that for determining the results of research decisions using the Fisher's test alternative test where in get the results of the $\mathrm{P}$ value of 0.006 so that the $\mathrm{p}$ value $<0.05$ Ho is rejected and Ha is accepted which means that there is an influence on the level of knowledge of 3 months injecting family planning acceptors in the intervention group after being given KIE side effects of using 3 months injectable family planning in BPM "L" Banjaranyar village.

From the results of the study, it was found that the number of respondents who had good knowledge was influenced by several factors, one of which was age, long experience of use, and the provision of IEC. Age affects a person's perception and mindset [6].As the age increases, the perception and pattern of thought will also develop so that the knowledge obtained is getting better where at that age the respondent already has experience, maturity in thinking and good grasping power so that it helps respondents in receiving knowledge. This is in line with Dedah Umilah's research with the title "Overview of Knowledge Levels of Injectable Family Planning Acceptors About Side Effects of Progestin Injecting Contraceptives at Gamping 1 Health Center, Sleman Yogyakarta." With the results of 55 respondents, 24 respondents (43.6\%) were knowledgeable enough with the respondent's age range from 20-35 years because at that age they were considered to have matured in thinking. [7]

Based on this research, experience is also one of the factors that affect a person's level of knowledge. A person tends to apply his previous experience to solve the problems he faces. The experience possessed by the respondent causes a person to have good analytical and synthesis skills, it can be seen from the length of use of the Injectable KB contraception, namely the majority of respondents have used Injectable $\mathrm{KB}$ for about 1-3 years, namely in the intervention group as many as 11 respondents (73.3\%) and 10 respondents $(66.6 \%)$. When viewed from the complaints where the control group is dominated by respondents who have been using contraception for a long time, it can be seen in the complaints felt by respondents in the control group tend to be fewer because the respondent's body has been able to adapt to the hormones given so that this is in accordance with the theory expressed. by Notoatmodjo that the better the analytical and synthesis skills a person has, the better the level of knowledge. So that in this study it appears that the intervention group needs IEC more because it is for adaptation adjustments and providing information about the treatment given. [5]

Based on the results of the research conducted, another factor that affects the level of knowledge is the provision of information through IEC, in line with Irmayati (2007) stating that information can be used as knowledge transfer [13]. According to (Notoatmodjo, 2003 in Sugeng, 2019), health communication is a systematic effort to positively influence public health behavior, using various principles and methods of communication, both using interpersonal communication and mass communication. Furthermore, it is also explained that the ease of obtaining information will accelerate a person to acquire new knowledge in addition to age, education and occupation as well as intelligence. [8]

Based on the results of the research obtained, it shows that there is a difference between the intervention group and the control group in the provision of IEC on the level of knowledge of the respondents. The results showed a significance value of $0.006<0.050$. From these results it can be concluded that $\mathrm{HO}$ is rejected and $\mathrm{Ha}$ is accepted so that there is an effect of giving IEC on the level of knowledge about side effects of 3-month injections between the intervention group and the control group. This means that the more respondents are given IEC regarding the Side Effects of this KB, the better the level of respondent's 
knowledge so that it can minimize the side effects caused by carrying out the treatment described through KIE. Handling side effects is very important because if it is not treated immediately, the mother who experiences side effects can cause excessive side effects.[9]

\section{CONCLUSION}

Based on the results of the research and discussion, it can be concluded that: There are 15 respondents $(100 \%)$ in the intervention group with good predicate, while the level of knowledge in the control group with good predicate is 8 respondents $(53 \%)$ and 7 respondents are not good predicate $(40 \%)$. There is an effect between the intervention group and the control group on the level of knowledge after giving IEC the side effects of using 3-month injectable contraception.

With this research, it is hoped that it can increase the knowledge and insight of researchers in applying knowledge later and can apply learning research methods obtained in academics and can be a reference material to continue in conducting further research, namely continuing research that is more varied and complex in order to obtain research results that are more comprehensive better.

\section{Acknowledgements}

Thank you to Allah SWT, both parents and all comrades in arms who have helped from beginning to end.

\section{REFERENCES}

[1] Apolonia,Ignata. "Gambaran Tingkat Pengetahuan Akseptor KB Hormonal Tentang Efek Samping Kontrasepsi Hormonal Di Puskesmas GentunganKabupaten Goa Tahun 2018”,Vol IV(No 7), November $2018: 48-58,2018$.

[2] BKKBN, “Pembangunan Kependudukandan KB”. Jakarta: BKKBN, 2015

[3] Kemenkes RI., ’Profil Kesehatan Indonesia Tahun 2019, Jakarta : Kemenkes RI, 2020.

[4] Budiman\&Riyanto A., "Kapita Selekta Kuisioner Pengetahuan Dan Sikap Dalam Penelitian Kesehatan”, Jakarta : Salemba Medika, 2013.

[5] Dedah Umilah Maswatu.,"Gambaran Tingkat PengetahuanAkseptor KB Suntik Tentang Efek Samping Kontrasepsi Suntik Progestin Di PuskesmasGamping 1 Sleman Yogyakarta. (KaryaTulisIlmiah). Stikes Jenderal Achmad Yani Yogyakarta, 2017.

[6] Dahlan,Sopiyudin., "Statistik Untuk Kedokteran Dan Kesehatan", Edisi 6, Jakarta, Salemba Medika, 2014.

[7] Notoatmodjo, S., "Ilmu Kesehatan Maayarakat Prinsip-Prinsip Dasar”.Jakarta: RinekaCipta, 2007.

[8] Mubarak, W.I., "Promosi Kesehatan”. Yogyakarta: GrahaIlmu, 2007.

[9] Handayani, S., "Buku Ajar Pelayanan Keluarga Berencana. Yogyakarta: PustakaRihama, 2010.

[10] Dinkes Pemalang., “ Profil Kesehatan Kabupaten Pemalang Tahun 2019”,Pemalang : DinkesPemalang, 2020.

[11] Febriyanto,M.A.B.,’Hubungan antara Pengetahuan dan Sikap Dengan Perilaku Konsumsi Jajanan Sehat di MI Sulaimaniyah Mojoagung Jombang”. (SKRIPSI). UniversitasAirlangga, 2016.

[12] Affandi,Biran., "Buku Panduan Praktis Pelayanan Kontrasepsi” „Jakarta:Yayasan Bina Pustaka Sarwono Prawirohardjo, 2016.

[13] Notoatmodjo., "Metode Penelitian Kesehatan ”, Jakarta : RinekaCipta, 2013.

[14] Hyttel,Maria.et al, "Use of injectable hormonal contraceptives: diverging perspectives of women and men,service providers and policymakers in Uganda', Reproductive Health Matters;20(40):148-157, 2012.

[15] Jitowiyono,S., Rouf,M.A., "Keluarga Berencana (KB) Dalam Perspektif Bidan”.Yogyakarta PT.PustakaBaru, 2019.

[16] Harahap, Irmayanti., "Hubungan Pengetahuan dan Pasangan Wanita Usia Subur (PUS) terhadap Pemakaian Kontrasepsi Kb Suntik 3 Bulan di Puskesmas Koni Kota Jambi Tahun 2015". Scietia Journal Vol5(No 01), Mei $2016: 8-13,2016$.

[17] Littlejohn.Krystale.E., "Hormonal Contraceptive Use and Discontinuation Because of Dissatisfaction: Differences by Race and Education”. Demography (2012) 49:1433-1452, 2012.

[18]Manuaba,Ida.A.C., Manuaba,Ida.B.G.F.,Manuaba,Ida.B.G., "Ilmu Kebidanan,Penyakit kandungan, dan KB untuk Pendidikan Bidan. (2th.Ed). Jakarta : EGC, 2010.

[19] Arikunto, S., "Prosedur Penelitian Suatu Pendekatan Praktik", Jakarta: RinekaCipta, 2010.

[20] Notoatmodjo, Soekidjo., "Metodologi Penelitin Kesehatan. Jakarta: RinekaCipta, 2005. 
[21] Dewi,Ayu.D.C., "Gambaran Efek Samping Kb Suntik Depo Medroksi Pogesteron Asetat Pada Akseptor di Bidan Praktik Mandiri (BPM) Wilayah Kerja Kelurahan Sako Palembang, Jurnal 'Aisyiyah Medika Vol 2. Agustus $2018: 38-43,2018$.

[22] DinkesJateng., “Profil Kesehatan Provinsi Jawa Tengah Tahun 2019”.Semarang : Dinkes Jateng, 2020. 